\title{
Ecologists clash over 'too academic' research
}

Basel. The Swiss National Science Foundation (NF) is planning to set up a new programme on applied biodiversity research, following criticism by ecologists working for non-academic organizations that too much money is going to academic projects with little immediate relevance to conservation.

The Swiss government originally announced in 1991 the launch of a biodiversity research programme costing SFr5 million (US\$3.5 million) for the three years 1993 to 1995 as part of its preparations for the 1992 Earth Summit in Rio de Janeiro.

By the spring of 1992, the NF had received almost 190 grant applications, most coming from independent ecologists or environmentalists working for Switzerland's many small conservation agencies. But only two of the 20 grants finally approved were given to researchers outside universities or academic research institutes.
Non-academic ecologists believe their chances of receiving a fair share of the funds were reduced by the fact that they were not represented on the 16-strong grant committee (though it included two industrialists).

The distribution of the funds also gave rise to charges of conflict of interest, as many of the grant recipients were academic colleagues known to the committee members. Rudolf Häberli, the NF official responsible for the biodiversity programme, denies that there was any wrongdoing, pointing out the difficulty in a country with a small scientific community of identifying scientists with no connection to each other.

Furthermore, one of the committee members who received a grant award says that he left the room when his application was being discussed. Nevertheless, sensitive to the criticisms, the NF has now changed its internal regulations covering participation

\section{Slovak university reforms stall}

Bratislava. The collapse of the Slovak government last week seems likely to bring new delays to university reforms designed to compensate for shortcomings in legislation introduced after the collapse of communism four years ago.

The reforms have already been stalled by a combination of the low priority given to academic issues by a succession of unstable governments and disagreement within the academic community over some of the proposed changes.

Czechoslovakia was the first Central European state to pass a new higher education law after the fall of communism. The 1990 act, which was intended to introduce Western-style values into the universities, is still valid in both of the independent republics into which the country split.

The new law set up an accreditation committee to set academic standards and decide the status of each of the 57 faculties in Slovakia's 14 universities. But the high level of autonomy given to universities in reaction to the external interference of communist times has had its price.

Each faculty is now independent, and there is very little inter-faculty cooperation. This means that university rectors have little power to coordinate the efforts of their universities as a whole, and therefore to carry out broad reforms.

Last September, the Ministry of Education, Youth and Sports set up an advisory committee to propose changes in the 1990 act that would make it more workable. But the committee's proposals have not been well received.

One point of controversy is the suggestion that rectors should be appointed as the head of university senates, and given the power to overrule decisions made by individual faculties. "This is how things work in Western European countries, and it is something that the committee is not prepared to compromise on," says Juraj Sinay, a committee member and pro-rector of the Technical University in Kosice, who claims that parliament agrees with this position.

Equally controversial is the issue of who should have the right to award PhDs. This time the opponents are the universities and the Slovak Academy of Sciences. In communist times, both gave research degrees, then known as candidate of science degrees.

But Miroslav Urban, a member of the accreditation committee, argues that with the recent establishment of Western-style $\mathrm{PhD}$ programmes, only universities should have the right to award such degrees.

Unsurprisingly, the academy is not happy with this arrangement. It has had the right to award doctorates since 1953, and is not ready to give this up without a struggle. But a compromise may be possible. Ján Kazár, scientific secretary of the academy, says its minimum requirement is "to participate in preparing colleagues for a scientific career".

If the reforms are passed by parliament in their present form, all university staff will face an evaluation of their competence, and their posts will become open to competition.

The reform committee is keen for the bill to be approved by parliament before the start of the autumn term, arguing that the apparent democracy of "faculty power" has been a block to true reform, as faculties have proved resistant to change. But the fall of the Slovak government makes this unlikely even if the academic community can decide what it really wants.

Alison Abbott in expert committees.

Häberli also denies that the allocation of research funding was unfairly biased towards university-based groups. He emphasizes that the applications were reviewed by international experts, and judged only on their scientific quality.

But Hans-Jörg Blankenhorn of the Swiss Game Directory, the body responsible for regulating game management and hunting regulations, is one of the critics who claim that the money should have been used more

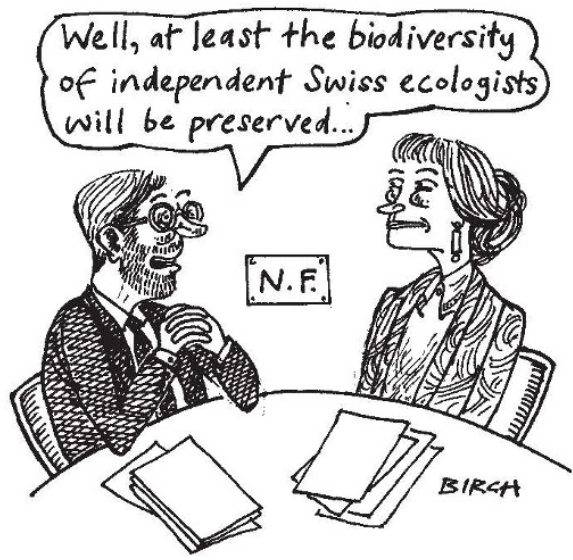

directly to tackle environmental problems.

He criticizes, for example, a SFr4 million grant to scientists at Basel University to support basic studies on the effect of habitat fragmentation on the genetics of populations, and the effect of increased carbon dioxide levels on grassland plant communities. But Bruno Baur, a zoologist who leads one of these projects, defends his research on the grounds that it does contribute to conservation, even if only in the longer term - a view officially supported by the NF.

Such arguments have failed to appease the critics, who argue that much more basic information is needed on the flora and fauna of Switzerland to help protect them, and that this is where more of the NF money should have gone. They also claim that some academic projects are being re-labelled as biodiversity projects merely to qualify for the new funds.

"Universities still look down on what we are doing", says Gabi Gerlach of the consultants BiCon AG in Kreuzlingen, one of the ecologists whose grant applications were rejected by the foundation.

The NF appears to be responding to such complaints. Last November, individuals whose proposals had been rejected were invited to take part in discussions on a new special programme of applied biodiversity research. The NF will decide in May whether to go ahead with the programme. If it gets government approval, the programme will be submitted to parliament for ratification in the summer of next year, and will be ready to start in 1996.

Oliver Klaffke 